\title{
Interpersonal communication within the family for improving adolescent religiosity
}

\begin{tabular}{|c|c|}
\hline \multicolumn{2}{|c|}{$\begin{array}{l}\text { Authors: } \\
\text { Christiana D.W. Sahertian }{ }^{1} \\
\text { Betty A. Sahertian }{ }^{2} \\
\text { Alfred E. Wajabula }\end{array}$} \\
\hline \multicolumn{2}{|c|}{$\begin{array}{l}\text { Affiliations: } \\
{ }^{1} \text { Ministry of Higher } \\
\text { Educations Religions, } \\
\text { Post-Graduate Program, } \\
\text { Ambon State Christian } \\
\text { Institute (IAKN), Ambon, } \\
\text { Indonesia }\end{array}$} \\
\hline \multicolumn{2}{|c|}{$\begin{array}{l}{ }^{2} \text { Ministry of Health, Health } \\
\text { Polytechnic, Maluku, Ambon, } \\
\text { Indonesia }\end{array}$} \\
\hline \multicolumn{2}{|c|}{$\begin{array}{l}{ }^{3} \text { Graduate Program, Faculty } \\
\text { of Theology, Indonesian } \\
\text { Christian University, Maluku, } \\
\text { Ambon, Indonesia }\end{array}$} \\
\hline \multicolumn{2}{|c|}{$\begin{array}{l}\text { Corresponding author: } \\
\text { Christiana Sahertian, } \\
\text { mayasahertian@gmail.com }\end{array}$} \\
\hline $\begin{array}{l}\text { Dates: } \\
\text { Received: } 23 \mathrm{~J} \\
\text { Accepted: } 25 \mathrm{~F} \\
\text { Published: } 30\end{array}$ & $\begin{array}{l}\text { uly } 2020 \\
\text { eeb. } 2021 \\
\text { Apr. } 2021\end{array}$ \\
\hline \multicolumn{2}{|c|}{$\begin{array}{l}\text { How to cite this article: } \\
\text { Sahertian, C.D.W., Sahertian, } \\
\text { B.A. \& Wajabula, A.E., 2021, } \\
\text { 'Interpersonal communication } \\
\text { within the family for } \\
\text { improving adolescent } \\
\text { religiosity', HTS Teologiese } \\
\text { Studies/Theological Studies } \\
\text { 77(4), a6267. https://doi. } \\
\text { org/10.4102/hts.v77i4.6267 }\end{array}$} \\
\hline \multicolumn{2}{|c|}{$\begin{array}{l}\text { Licensee: AOSIS. This } \\
\text { is licensed under the } \\
\text { Creative Commons } \\
\text { Attribution License. }\end{array}$} \\
\hline \multicolumn{2}{|l|}{ Read online: } \\
\hline 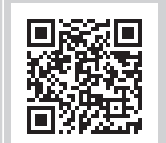 & $\begin{array}{l}\text { Scan this QR } \\
\text { code with your } \\
\text { smart phone or } \\
\text { mobile device } \\
\text { to read online. }\end{array}$ \\
\hline
\end{tabular}

Authors:

Betty A. Sahertian ${ }^{2}$ (I)

Alfred E. Wajabula ${ }^{3}$ (I)

\section{Affiliations:}

${ }^{1}$ Ministry of Higher

Post-Graduate Program,

Ambon State Christian

Institute (IAKN), Ambon

Indonesia

${ }^{2}$ Ministry of Health, Health Polytechnic, Maluku, Ambon,

${ }^{3}$ Graduate Program, Faculty of Theology, Indonesian Christian University, Maluku, on, Indonesia

Corresponding author:

Christiana Sahertian

Dates:

Received: 23 July 2020

Accepted: 25 Feb. 2021

How to cite this article: Sahertian, C.D.W., Sahertian, within the family for improving adolescent 77(4), a6267. https://doi. org/10.4102/hts.v77i4.6267

Copyright:

Licensee: AOSIS. This work

is licensed under the

Creative Commons

Attribution License.
National education is a conscious and planned effort to help children develop their potential be spiritually strong, religious, intelligent, a strong personality and noble character and noble skills. For this reason, education not only focuses on the aspect of children's knowledge but also on religion and morals aspects. This education begins in the family through communication patterns that are created between parents and children in the form of interpersonal communication that can increase the religiosity of adolescents. Therefore, this article aims to measure the interpersonal communication within the family. The author uses quantitative methods with technical correlation to determine the relationship between two variables, namely interpersonal communication in the family and youth religiosity, and includes 303 adolescents as a sample. The data were collected using a Likert scale and processed using Excel and SPSS 16 programs in order to obtain the results that the application of good interpersonal communication in families will increase adolescent religiosity. This leads to the conclusion 'there is a mutually influential relationship between interpersonal communication in the family and adolescent religiosity'.

Contribution: This article contributes to Christian families in increasing interpersonal communication as a pattern of youth formation, because it can increase their religiosity.

Keywords: interpersonal communication; family; adolescent religiosity; spirituality; education.

\section{Introduction}

Family is an educational institution. It is the first institution in the a person gets to know before formal education (Rahmah 2017). Everyone in the family will experience changes and developments according to the colour and pattern of each family. In addition, a family environment is the first and foremost educational environment for children (adolescents), because family is the first place where a child receives education and guidance. This education and guidance mark a large part of the child's life in the family. The family which is referred here is an institution comprising the husband, wife and children - the immediate or nuclear family (Browning 2007).

Education is generally understood as 'a way to develop skills, habits and attitudes, which are expected to make a person a good citizen'. The purpose of education is to develop or change a person's cognitive, affective and psychomotor traits (Harianto 2012). According to Yunus (1990),

Education is an effort that is deliberately chosen to be able to influence and help children with the aim of being able to improve knowledge, body and morals so that it can slowly lead children to their highest goals and ideals. (p. 48)

In addition, in the Indonesian context, there is the National Education System Law (UU Sisdiknas No. 20 of 2003) (Harianto 2012), which defines education as,

$[A]$ conscious and planned effort to create an atmosphere of learning and the learning process so that students actively develop their potential to have power, religious spirituality, self-control, personality, intelligence, noble character, and skills needed by him and society. (p. 49)

Based on this definition, Christian Religious Education is a conscious and planned effort to highlight the role of Jesus Christ (2 Cor 3:13) in laying the foundation for the growth of Christian faith by creating a learning atmosphere and a learning process so that students actively develop their potential so as to obtain spiritual strength based on self-control, personality, intelligence, noble character and skills needed by himself and society. Since Christians are followers of Christ, Christian religious education puts the foundation of its teaching on the teachings and actions of Jesus (Harianto 2012). 
Education in general and according to the understanding of Christianity as mentioned here starts from the family. Parents have the major responsibility in the family and greatly influence the personality development of adolescent. This responsibility is handled by conducting coaching within the family, and amongst others, through the communication patterns between parents and their children. If the parents' communication is good, it will have an impact on the child and also on the social environment of the child in his interactions. So the function and role of parents (father and mother) is very important, namely as a guide, teacher and primary educator for children (Jailani 2014).

The intended communication pattern is interpersonal communication. Interpersonal communication is communication that occurs between parents and children. This interpersonal communication is a form of sending and receiving messages between two persons or between a small group of persons, followed by immediate feedback (DeVito 1989). In addition, this interpersonal communication also takes place in face-to-face situations between two or more persons, either in an organised manner or in a crowd of people (Awi, Mewengkang \& Golung 2016). This kind of communication must occur in the family.

In building this communication, the family has a strong role and influence in shaping the personality of adolescents (Rahmah 2017). This strong influence is related to the role of each family member. This role is a unitary system (Awi et al. 2016). This interaction must be balanced. The family balance is characterised by the harmonious relationship between both parents and the relationship of parents with their children. This harmony occurs when all family members feel happy, which is marked by reduced tension and disappointment and satisfaction with their entire state and existence (existence and self-actualisation). It includes physical, mental, emotional and social aspects (Gunarsa 2004). Family harmony can be also exist if each element in the family is able to function and have a role as it should be and still adhere to religious values (Hawari 1997). This harmony creates conducive conditions for the growth and development of adolescent personalities to become good children according to the given educational goals. Thus, this conducive condition is an important condition for good interpersonal communication, especially between parents and children. Through this interpersonal communication, parents as a source of messages provide religious messages or advice that will affect the level of children's religiosity.

In addition, interpersonal communication in the family is also reflected in the attention of parents towards children. This attention is in the form of advice, reprimand, punishment, praise and invitation. These are forms of interpersonal communication which play a major role in shaping the personality of adolescents. For example, when a child is reprimanded for making a mistake, it will determine the involvement of the teenager in carrying out his religious teachings. Likewise, praising children who often do good deeds in accordance with religious values will encourage them to do good in the future. The same is true when communication is built up through invitations to do well and leave bad deeds. The invitation can take the form of religious activities at home or other activities outside the home.

These facts show that there is a relationship between interpersonal communication and a person's level of religiosity. This means that the more parents try to communicate facts related to the experience of religiosity for adolescents, the higher is the religiosity of the adolescents. On the other hand, reduced interpersonal communication within family, will also affect the level of involvement of adolescents in carrying out religious teachings.

Moreover, the parents (father and mother) who are the focus of this research (not single parents), act as originators of introductory changes for the child in the family, so that the child becomes an adult and enhances the image of the family in the community. The process of introducing religious norms and values will be more effective through interpersonal communication within the family (father - mother - child).

From the discussion so far, it can be concluded that the higher the interpersonal communication in the family, the higher the religiosity of adolescents. Vice versa, the lower the interpersonal communication of adolescents with their families, the lower the level of involvement in practicing their religious teachings. So it is suspected that there is a positive relationship between interpersonal communication in the family and the religiosity of adolescents.

Referring to the given description, this study assumes that by optimally implementing interpersonal communication in the family, there is an increase in adolescent religiosity.

\section{Literature review}

\section{The concept of interpersonal communication in the family}

Communication (from Latin: communication) comes from the word communis that means: the same meaning. This means that language and its meaning have one meaning. For example, a conversation between two individuals can be said to be communicative, if they can understand the language and its meaning from the material being discussed (Barseli et al. 2019). So, communication can be understood as a process in which humans acquire knowledge, influence one another and create and maintain a common basis for social reality, which is then used for personal direction and sharing. In addition, communication is a process of delivering and receiving messages in the form of information, thoughts or emotions and feelings from one person or group to another person or group of persons and groups. From this meaning it can be understood that communication is broad, but the activities of various information and communication itself are specific, namely the process of transferring messages from source to source (Shubert 2011). With communication 
human knowledge can increase and mutual understanding between them can be realised.

Interpersonal communication here refers to the delivery of messages by one person and receiving messages by other people or a small group of people, with various effects and with the opportunity to provide immediate feedback (Effendy 2003). Mulyana emphasises the same definition, by emphasising face-to-face communication between persons, which allows each participant to perceive the reactions of others directly, either verbally or nonverbally. Therefore, according to him, this interpersonal communication is communication that occurs only between two persons, such as husband and wife, two colleagues, two close friends, teacher-student and so on (Mulyana \& Jalalludin 2005). In other words, interpersonal communication can basically be understood as a form of personal communication that occurs face-to-face between individuals and allows each actor to capture other person's reactions directly both verbally and non-verbally (Sihabudin 2014).

From these definitions it can be understood that interpersonal communication between parents and adolescents can occur optimally because the distance between the communicator and the communicant is very less. Likewise with a very close physical relationship (conversation, advice, sharing), interpersonal communication between parents and adolescents in a family can be very effective. In the same way, feedback is expected to occur immediately because it is direct and face to face. Here, the role of parents is very important in imparting religious values to children because they receive immediate feedback (Baharun 2016). As soon as the parents give advice, the children can understand what the parents mean. Even the feedback given is not only understandable but it also has scope for arguments or questioning. Therefore, in this interpersonal communication the opportunity for dialogue between parents and children is vast, especially whilst discussing religious issues.

In this study, the relationship between interpersonal communication variables and adolescent religiosity can be explained as follows. Parents are the source of religious messages and children are the recipients of religious messages. This means that the more messages of religious communication conveyed by parents to their children, the greater will be impact on children's religiosity. This impact can occur because the family member closest to the child is the parent. Parents referred to here are the father and mother, where their position in giving messages or religious advice is the same.

With regard to this, these variables are described in several indicators that refer to the theory of 'Self Disclosure', which is a type of communication, where information about oneself is usually kept secret but is communicated to others or is a process of disclosing information about yourself to others. This theory was put forward by Sydney Marshall Jourad and Josep Devito (Saputri 2018) in their book, The Interpersonal Communication (Barseli et al. 2019; DeVito 2008, 2011) and states, 'that there are five criteria for realising effective interpersonal communication skills', namely:

- Openness includes the desire to share information about oneself, the desire to react honestly to messages conveyed by others and to be responsible for their feelings in the sense of not scapegoating others.

- Empathy is the ability to feel and experience what other persons feel, namely trying to feel in the same way as other person. The accuracy of empathy includes sensitivity to sense current events and being able to understand the words spoken during interpersonal communication. We can communicate empathy both verbally and nonverbally. Nonverbally, we can communicate empathy by showing:

- Active involvement with the person through facial expressions and appropriate gestures.

- Concentration that includes eye contact, attentive posture and physical closeness.

- Appropriate touching or caressing (Awi et al. 2016).

- Supportiveness needed in interpersonal communication, includes four aspects, namely:

- Descriptiveness; a descriptive environment, which is an environment that does not judge people evaluatively so that people tend to be deficit. People who feel that they are being evaluated will be ashamed to express their feelings freely and feel constantly criticised.

- Spontaneity; individuals who communicate spontaneously, namely those who have the foresight and are best at expressing their thoughts.

- Provisionalism is being more open, willing to accept the views of others and willing to change their position or point of view if necessary.

- Unspoken support in the form of nodding their head, winking and smiling.

- Positiveness in interpersonal communication in at least two ways, namely based on a positive attitude and respect for others, consisting of three things, namely:

- Positive attention to others which strongly supports the success of interpersonal communication.

- Positive feelings are very useful for effective collaboration.

- Positive attention and feelings must be communicated so that interpersonal communication can be well maintained.

- Equality is an element of desire to work together in solving problems, this is manifested in viewing disagreements and disputes between communicating individuals, more as an attempt to understand the differences that exist, rather than seeing them as opportunities to bring down each other.

Based on the given explanation, interpersonal communication can be mapped. The indicators used to achieve the effectiveness of this research and to answer the hypothesis are openness, empathy, a supportive attitude, a sense of positivity and equality. 


\section{Concept of religiosity}

Religiosity is derived from the word religion (English), religy (Indonesia) or in Latin words, religious (is an adjective of the noun, religio), relegere (re-eligere, re-elect) or religure (re-ligare), which means to tie back (Hardjana 2005). In addition, the word relegare also means to be careful and stick to norms or rules strictly (Ghufron 2017). There is also another definition according to Boadella (Reyes 2006): reconnecting with a deeper source. The point is an obligation or rule that must be carried out, all of which serve to bind and confirm a person or group of people in relation to God or fellow human beings, as well as the natural surroundings (Ghufron 2017). In this sense, it can be understood that religiosity is a comprehensive unity of elements, which makes a person referred to as a religious person (being religious), and not merely claiming to have religion (having religion). Religiosity includes religious knowledge, religious beliefs, practice of religious rituals, religious experience, religious behavior (morality) and socioreligious attitudes (Fitriani 2016).

On the other hand, according to Hendropuspito, religion (religion) is seen as an institution that regulates statements of faith in open forums or communities and its manifestations can be seen and witnessed in the form of rules, rites, cults, prayers and others (Hendropuspito 1983). Here we can see a number of expressions such as religious symbols, certain patterns of behaviour, methods of mission, houses of worship and so on. Therefore, talking about religion means talking about how to feel, how to think, how to act and how to deal with other people, because in principle religion aims to regulate all aspects of human life. Religion therefore has a social control function of person's behaviour and is also responsible for the good norms that are applied to society. With religion, everyone's behaviour is required to be in accordance with the teachings of their religion.

The same thing happened to adolescents, where adolescents with their daily behaviour were determined based on the values of their religious teachings. According to Glock and Stark (Glock \& Stark 1970; Jalaludin 2005), religiosity has three criteria, amongst others: (1) a person's level of belief, (2) how often they participates in religious activities in places of worship (church, unit, sector, etc.), (3) how important is worship to them and how often do they worship. From this explanation, of course there is a relationship between a person's behaviour and his religious experience. This means that people who have good religious experience will tend to do good because religion in principle is a guide for someone to move things that are good in world affairs and in the affairs of the later life (James 2014).

In addition, Hendropuspita also emphasised that a person's religiosity can be known through five dimensions, including (1) ritual involvement which indicates the extent to which a person carries out his rituals in daily life, such as church worship, unit worship, youth or youth worship or other religious services and events, (2) ideological involvement which is related to one's acceptance of things that are dogmatic. For example, belief in the existence of God in life, (3) intellectual engagement is the involvement of a person who contributes with the ability to think for religious purposes. For example, solving religious problems, presenting ideas to preach religion and trying to deepen religious knowledge, (4) religious experience means realising God's miracles, for example, surviving danger because of God's help, feeling successful because of God,(5) experiencing religious teachings in everyday life, which means that in all daily behaviour followed by the teachings of the religion he adheres to (Hendropuspito 1983).

Discussions about religious issues in the family and with other people are an important indicator in determining a person's level of religiosity. People who often talk about religious matters indicate having a high commitment to maintaining and developing their religion, including efforts to invite people to worship. Measurement of the level of religiosity can be seen in three dimensions of religious involvement, namely involvement of the mind, physical involvement and financial involvement. Adolescents who have never been involved in religious activities, both ritual and non-ritual, have low religiosity.

Based on the given description, what is meant by religiosity in this research is a person's diversity which includes (1) belief/ideology, (2) religious/ritualistic practice, (3) religious experience, (4) consequences and (5) religious knowledge.

\section{Adolescents}

The word Adolescents according to Elizabeth Hurlock in Gatot Marwoko, comes from the Latin word adolescere, which means to grow or to grow in maturity (meaning: to grow or grow to be an adult). The term adolescence as used today has a broader meaning, including mental, emotional, social and physical maturity (Marwoko). Likewise J.J. Rousseau in his book 'Emila' discusses in detail the development of children, which specifically talks about the 12-15 year period, which he calls the age of reason (Darmawan 2006), namely the developmental period in which children begin to think critically because it is a transition period from adolescence to adulthood. This transitional period caused many physical and psychological changes. These changes in turn cause inner turmoil, so it is often called the period of the transition or storms and typhoons, Storm and Stress or Strum and Drang (Sarwono 2011).

It is called the transition period because at this time a person is full of emotions and sometimes emotions explode because of conflicting values. These emotions make things difficult, both for the teenager and for the parents or adults around him. However, this emotion is also useful for adolescents in an effort to find their own identity, because it will be a learning experience for the teenager to determine what actions to do in the future. In addition, important social changes in adolescence include the increased influence of peers (peer groups), more mature social behaviour patterns, 
the creation of new social groups and the emergence of new values in choosing friends and leaders and values in social acceptance (Krori 2011). Herein lies the importance of the role of parents as primary and first educators in the family.

Adolescence according to the World Health Organization's (WHO) conceptual definition involves biological, psychological and socio-economic criteria. Thus, adolescence is a period in which: (1) the individual develops from the first time he shows development of secondary sexual characteristics to the time he reaches sexual maturity (biological criteria), (2) individuals experience psychological development and identification patterns from childhood to adulthood (social-psychological criteria), (3) there is a shift from a full socio-economic dependence to a relatively more independent state (socio-economic criteria) (Sarwono 2011). Related to that, Hurlock (1990) divides adolescence into two phases, namely (1) early adolescence (11 to 15 years old), and (2) late adolescence (16 to 18 years old). In late adolescence, individuals have reached a developmental transition leading to adulthood.

So what is meant by adolescence is a period of human age where the maximum changes (transition) occur. During this period, adolescents also try to form their own identity and personality, so the failure at this phase will make them lose their confidence and personality. He does not know his role as a human being in this stage of life.

\section{Methodology \\ Research design}

This study uses a quantitative method using correlational techniques. Research using correlational techniques is research that is intended to determine whether or not there is a relationship between two or more variables; with correlational techniques a researcher can determine the relationship between variations in a variable and other variations, the magnitude or height of the relationship is expressed in the form of a correlation coefficient (Arikunto 2013).

\section{Research variable}

In the context of this research, the effect of interpersonal communication in the family was treated as an independent variable $(X)$ with adolescent religiosity as the dependent variable $(Y)$. To analyse the data descriptive analysis and simple linear regression analysis was used with one independent variable and one dependent variable.

\section{Population and sample}

The population in this study is a limited population where the generalisation area consists of subjects that have certain qualities and characteristics that the researcher applies to the study so that conclusions can be drawn (Sugiyono 2019). The population of this study included 303 adolescents in six sectors (regions) in the Imanuel-OSM (Oplijding School Marine) GPM Congregation, Ambon City, Maluku Province, Indonesia. ${ }^{1}$

From this population samples were drawn by using the Stratified Random Sample technique to segregate the population elements into groups called strata and then selecting a sample randomly from each stratum (Sugiyono 2019). Therefore, in this study the researchers used four sectors as the research sample, namely the Ebenhaser sector (Gudang Arang, Kampung Timur), Maranatha sector, Sion sector and Bethabara sector. These four sectors were chosen because they are close to each other and juvenile delinquency often occurs. For the Petra and Gilgal sectors, researchers were used as sample testing instruments. Therefore, the sample comprising 172 adolescents was used.

\section{Sample}

The sample according to Sugiyono (2019) is part of the number and characteristics of the population. This study uses a sampling technique carried out through a Stratified Random Sample. Stratified Random Sample is a sample that is drawn by separating the population elements in groups called strata and then selecting a random sample from each stratum.

In this study, the researchers used four sectors as research samples, namely the Ebenhaesr sector (Gudang Arang, Charcoal warehouse; Kampug Timur, East Village), Maranatha sector, Sion sector and Bethabara sector. These four sectors were considered because the four sectors are close to each other and juvenile delinquency often occurs.

\section{Sample determination}

From the given calculations, the minimum sample size in this study was 172 adolescents. The sample of 172 adolescents can be seen in Table 2 .

\section{Data-collection technique}

This study used data-collection techniques by employing a questionnaire containing questions that are circulated using a Likert scale with five answer choices. Instrument preparation is carried out and tested so that it meets valid and reliable requirements. For the analysis of the validity and reliability of items of interpersonal communication in the family, SPSS (Statistical Product and Service Solutions) version 16.0 was tested for 59 adolescents who met the requirements of 47 statements from 51 questions. As for the validity and reliability of adolescent religiosity, 37 questions out of 40 questions were used.

1.The Imanuel OSM congregation is one of the congregations in the Protestant Church of Maluku (Gereja Protestan Maluku, GPM), which is geographically located in the Ambon City Government area. This congregation includes precisely three villages: Ambon City Government area. This congregation includes precisely three villages:,
Wainitu, Fort and Kudamati Kelurahan. Ambon itself is the capital of Maluku Province, which is in the eastern part of the Republic of Indonesia. 
TABLE 1: Population of youth in Immanuel OSM Congregation.

\begin{tabular}{llc}
\hline Number & Sector name & Number of adolescents \\
\hline 1 & Ebenhaezer & 50 \\
2 & Bethabara & 32 \\
3 & Sion & 53 \\
4 & Maranatha & 64 \\
5 & Petra & 35 \\
6 & Gilgal & 69 \\
\hline Total & - & $\mathbf{3 0 3}$ \\
\hline
\end{tabular}

TABLE 2: Sample of adolescents in the Imanuel Oplijding school marine congregation based on the sector.

\begin{tabular}{llcc}
\hline Number & Sector name & \multicolumn{2}{c}{ Adolescents } \\
\cline { 3 - 4 } & & Number & Percentage (\%) \\
\hline 1 & Ebenhaezer & 50 & 29 \\
2 & Bethabara & 32 & 18 \\
3 & Sion & 53 & 30 \\
4 & Maranatha & 64 & 36 \\
5 & Petra & 35 & 20 \\
6 & Gilgal & 69 & 39 \\
\hline Total & - & $\mathbf{3 0 3}$ & $\mathbf{1 7 2}$
\end{tabular}

TABLE 3: Correlation between interpersonal communication in family and adolescents religiosity.

\begin{tabular}{lccc}
\hline Variable & $r_{x y}$ & Sig. $(p)$ & Information \\
\hline $\begin{array}{l}\text { Interpersonal communication in the family } \\
\text { Adolescent religiosity }\end{array}$ & $0.811^{*}$ & 0.000 & $p>0.05$ \\
\hline
\end{tabular}

Sig., significance; $r_{x y}$ correlation coefficient.

*The higher the interpersonal communication in the family, the higher the adolescent religiosity.

\section{Data analysis technique}

The data management technique is implemented using quantitative methods with descriptive analytical methods. Descriptive statistics are used to find the mean and standard deviation. Data processing was performed using Excel and SPSS 16 programs.

\section{Results and discussion \\ Research results \\ Data description about interpersonal communication in families}

Data related to interpersonal communication in the family regarding adolescent statements, namely (1) the openness of adolescents in the family, which is related to 14 questions, (2) the attitude of empathy of adolescents in the family, which is related to nine questions, (3) the supportive attitude of adolescents with seven questions, (4) positive attitude ranging from adolescents to families related to six questions and (5) youth equality in the family with nine questions. All these data were based on a Likert scale (1-5) with the options of strongly agree, agree, doubt, disagree and strongly disagree.

The average results of the description related to the openness of adolescents in the family who answered strongly agree (17.29\%), answered agreed (68.36\%), answer doubt $(0 \%)$, answered disagree $(21.43 \%)$ and strongly disagreed $(5.93 \%)$. The mean results of the description related to the empathy attitude of adolescents in the family who answered strongly agree (17.78\%), answered agreed (66.56\%), answered doubtful $(0.33 \%)$, answered disagree $(21.78 \%)$ and strongly disagreed (6.22\%).

The mean results of the descriptions related to the supportive attitude of adolescents in the family who answered strongly agree $(17.14 \%)$, answered agreed $(68.86 \%)$, answers doubtful $(0 \%)$, disagreed $(21 \%)$ and answered strongly disagreed $(6 \%)$. The mean of the results of the description related to the positive attitude of adolescents in the family who answered strongly agree were $(20.17 \%)$, answered agreed $(64.33 \%)$, doubtful $(0.17 \%)$, disagreed $(21.67 \%)$ and strongly disagreed (6.67\%).

The mean of the results of the description related to the equality of adolescents in the family who answered strongly agree $(17.78 \%)$, whilst the attitude of adolescents who answered agreed was $(66.67 \%)$, whilst the answers of adolescents who were doubtful were $0.33 \%$, adolescents who disagreed $(21.78 \%)$, whilst those who answered strongly disagreed with $6.44 \%$.

An overview of the data on adolescent interpersonal communication attitudes in the family can be seen in Figure 1.

\section{Data description about adolescent religiosity in the family}

Data related to adolescent religiosity in the family, namely (1) the dimensions of adolescent beliefs related to seven questions, (2) the dimensions of religious practice related to seven questions and (3) the consequence dimensions of six questions. These data were based on a Likert scale (5-1) with the values of strongly agree, agree, doubt, disagree and strongly disagree.

The mean of the results of the description related to the attitude of religiosity associated with the belief dimensions of adolescents who answered strongly agreed (39\%), answered agreed (50\%), answers doubtful (3.9\%), disagree (11.4\%) and strongly disagreed (8.7\%).

The mean of the results of the description related to the attitude of religiosity associated with the dimensions of adolescent beliefs who answered strongly agreed (29\%), answered agreed (57.88\%), answers doubtful (1.25\%), answered disagree (15.13\%) and strongly disagreed $9.75 \%$.

The mean results of the description related to the attitude of religiosity related to the consequence dimensions of adolescents who answered strongly agreed (29.17\%), answered agreed (46.17\%), answers doubtful (1.67\%), disagree (19.83\%) and strongly disagreed $(16.17 \%)$.

An overview of the data on increasing adolescent religiosity can be seen in Figure 2.

\section{Correlation between interpersonal communication in family and adolescents religiosity}

The result of the hypothesis test that says: 'there is a positive correlation between interpersonal communication in the family and youth religiosity in Imanuel OSM', shows a correlation coefficient $\left(r_{x y}\right)$ of $0.811\left(^{*}\right)$ with a 


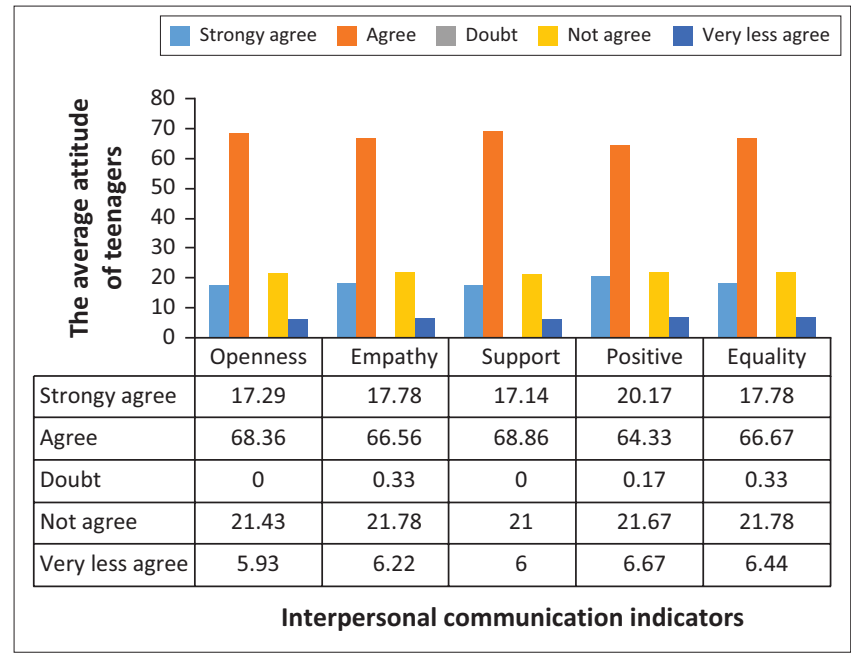

FIGURE 1: Interpersonal communication in the family.

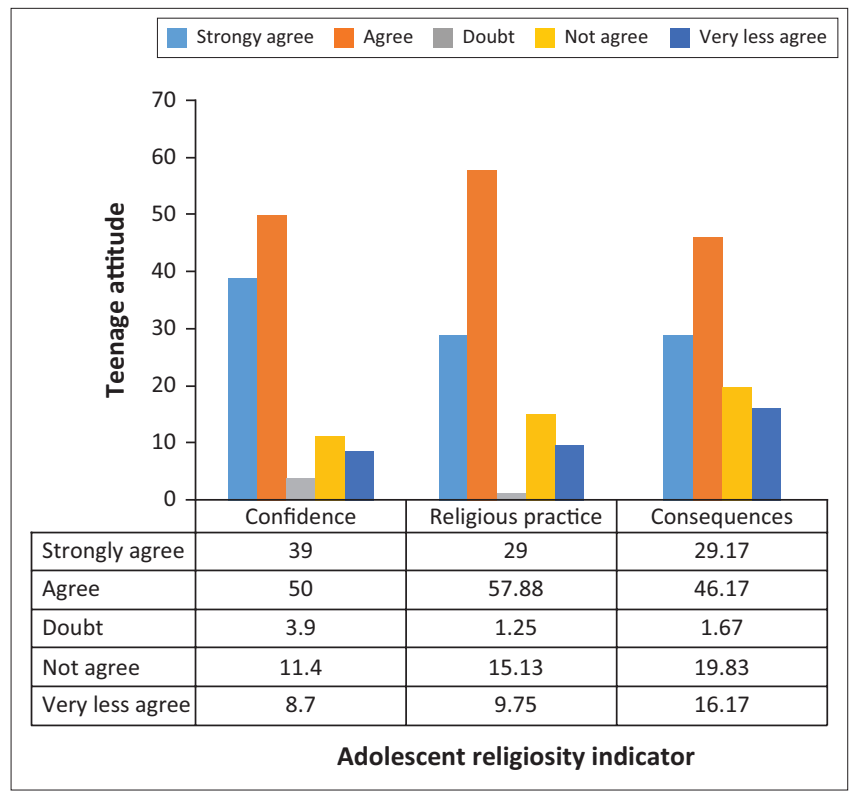

FIGURE 2: Adolescent religiosity.

value of $p=0.000$. The correlation coefficient of $0.811\left(^{*}\right)$ indicates a strong correlation between interpersonal communication in families and adolescent religiosity ( 0.811 over 0.5$)$. More often or always there is interpersonal communication in the family; the better it is the better is the teenage religiosity and vice versa. Sign (*) indicates that the higher the interpersonal communication in the family, the higher the adolescent religiosity. As the interpersonal communication variable is only 25 , whilst the religiosity of adolescents is 15 , then the $N$ values displayed are 25 and 15 . This is in accordance with the correlation used by the researcher.

\section{Ethical considerations}

This article follows all ethical standards for a study, such as keeping the respondent's secret, establishing verbal communication with the respondent according to prevailing manners and customs. The questions posed in the questionnaire sheet still follow scientific stipulations.

\section{Discussion}

\section{Interpersonal communication within the family}

From the research results in Figure 1, it can be seen that adolescents are very open to both their parents and their siblings. The openness of adolescents is one of the factors of effective interpersonal communication. This factor can bring them closer to their family, so that they can share stories with their parents and other family members. This is also supported by data showing that adolescents do not hesitate to open up to them.

In addition to being open, the teenager also showed empathy in the family as evidenced by a very large percentage of agreeing and strongly agreeing answers. This empathetic attitude is shown through actions such as congratulating families for achievements, helping to overcome family difficulties, treating sibling/siblings well, being a loyal listener or confidant, understanding the feelings of parents or relatives. He can also accept the differences that exist in the family.

The attitude of empathy that exists in teenagers causes them to receive full family support or an attitude that shows this support. This is evidenced by the largest percentage of agree and strongly agree. The supportive attitude of adolescents can be seen through his way of honouring family members, supporting good things that are obtained from the family, praising younger siblings, always encouraging friends who need help. This can also be demonstrated in positive attitudes demonstrated by adolescents such as appreciating the differences in the characteristics of others, asking for the willingness of parents if they want to ask questions, asking for input when teenagers make mistakes, always thinking positive things towards others, besides always respecting friends without looking at social, economic, ethnic and religious backgrounds.

Data on the equality of adolescents in the family who strongly agree and agree more show that they are better recognised compared to those with doubt, or answers disagree and strongly disagree. This means that teenagers can get along naturally with anyone, teenagers are active in religious activities, like to discuss and understand the feelings of others.

\section{Youth religiosity in the family}

The results showed that adolescent religiosity associated with religious beliefs, practices and consequences of adolescents was generally good. This goodness can be seen in the percentage of adolescent belief variables, which shows the highest number of agree (44\%) and strongly agree $(35 \%)$. The dimensions of this belief include: belief in the existence of God, understanding of the scriptures or belief in God's punishment and mercy on human actions. This shapes the youth's personality. This personality is in line with the youth's participation in practicing 
their beliefs, such as prayer and thanksgiving before/ after doing activities, being able to spend time regularly reading the Bible or being involved in other religious activities.

The awareness of adolescent religiosity that was formed brought him to a situation of living in accordance with the religious values he believed in. These religious values include being forgiving, not easily giving up, being helpful and being critical of dire situations, not repaying with evil but with tenderness and love.

\section{Correlation between interpersonal communication in families and youth religiosity}

Based on the results of the research hypothesis testing using the correlation test between interpersonal communication in the family, it was found that the adolescent religiosity was good. This shows that the higher the interpersonal communication in the family, the higher or better the adolescent religiosity. Good adolescent treatment occurs because of good communication in the family. Devito said that interpersonal communication can be successful if there is openness, empathy, support, positive feelings and equality. An open family that always provides empathy and provides support and treats adolescents equally can give birth to good beliefs, religious practices and religious consequences.

\section{Conclusion}

Adolescent religiosity in this study has increased significantly because interpersonal communication in the family is optimal. This interpersonal communication is implemented by the nuclear family who is the main educator.

Based on the research results, it is known that this research hypothesis is accepted, which means that there is a significant relationship between interpersonal communication in the family and adolescent religiosity.

\section{Acknowledgements}

The authors acknowledge the following: (1) Leadership and staff of the GPM Congregational Council Imanuel OSM, Ambon, Maluku Province, Indonesia, (2) Ambon IAKN Chancellor, Dr. Agustina C. Kakiay, M.Si, (3) the board of directors, AOSIS publisher and staff of the HTS Theological Studies journal.

\section{Competing interests}

The authors declare that they have no financial or personal relationships that may have inappropriately influenced them in writing this article.

\section{Authors' contributions}

C.D.W.S., B.A.S. and A.E.W. contributed to the design and implementation of the research, to the analysis of the results and to the writing of the manuscript.

\section{Funding information}

This research received no specific grant from any funding agency in the public, commercial or not-for-profit sectors.

\section{Data availability}

The data used are obtained from research conducted in the Imanuel OSM congregation, Wainitu village, Nusaniwe sub-district, Ambon, Maluku province, Indonesia. These data are used for analysis and the results are published in this article.

\section{Disclaimer}

The views and opinions expressed in this article are those of the authors and do not necessarily reflect the official policy or position of any affiliated agency of the authors.

\section{References}

Arikunto, S., 2013, Prosedur Penelitian: Suatu Pendekatan Praktik, rev. edn., Rineka Cipta, Jakarta.

Awi, M.V., Mewengkang, N. \& Golung, A., 2016 'Peranan Komunikasi Antar Pribadi dalam Menciptakan Harmonisasi Keluarga di Desa Kimaam Kabupaten Merauke', Acta Diurna Komunikasi 5(2), 1-12.

Baharun, H., 2016, 'Pendidikan Anak dalam Keluarga: Telaah Epistemologis', Pedagogik: Jurnal Pendidikan 3(2), 126. https://doi.org/10.33650/pjp.v3i2.126

Barseli, M., Sembiring, K., Ifdil, I. \& Fitria, L., 2019, 'The concept of student interpersonal communication', Jurnal Penelitian Pendidikan Indonesia 4(2), 129-134. https://doi.org/10.29210/02018259

Browning, W.R.F., 2007, Kamus Alkitab, BPK Gunung Mulia, Jakarta.

Darmawan, A.I.P., 2006, 'Pendidikan "back to nature": Pemikiran Jean Jacques Rousseau Tentang Pendidikan', Satya Widya 32(1), 11-18. https://doi.org/ 10.24246/j.sw.2016.v32.i1.p11-18

DeVito, J.A., 1989, The nonverbal communication workbook, Waveland Press, Prospect Heights, IL.

DeVito, J.A., 2008, 'The interpersonal communication book', PsyCCRITIQUES 32(1), 86. https://doi.org/10.1037/026727

DeVito, J.A., 2011, Komunikasi Antarmanusia, Karisma Publishing Group, Jakarta.

Effendy, O.U., 2003, Ilmu Teori Dan Filsafat Komunikasi, Citra Aditya Bhakti, Bandung.

Fitriani, A., 2016, 'Peran Religiusitas Dalam Meningkatkan psychological well being', Al-Adyan 11(1), 57-80.

Ghufron, M.N., 2017, 'Spiritualitas Dan Kesuksesan Belajar: Studi Meta Analisis', Edukasia: Jurnal Penelitian Pendidikan Islam 11(2), 355-376. https://doi.org/ 10.21043/edukasia.v11i2.1774

Glock, C.Y. \& Stark, R., 1970, American Piety: The nature of religious commitment, University of California Press, London.

Gunarsa, S., 2004, Dari Anak Sampai Usia Lanjut, BPK Gunung Mulia, Jakarta. Hardjana, A.M., 2005, Religiusitas, Agama Dan Spiritualitas, Canisius, Jokjakarta.

Harianto, G.P., 2012, Pendidikan Agama Kristen Dalam Alkitab \& Dunia Pendidikan Masa Kini, 16th edn., Andi Offset Yogyakarta, Yokyakarta.

Hawari, D., 1997, Alquran IImu Kedokteran Jiwa dan Kesehatan Mental, Dana Bhakti Yasa, Jakarta.

Hendropuspito, D., 1983, Sosiologi Agama, 22nd edn., Canisius, Jokjakarta.

Hurlock, E., 1990, Developmental psychology; A lifespan approach, Erlangga Gunarsa, Jakarta.

Imanuel OSM congregation strategic plan 2016-2020, unpublished working document.

Jailani, M.S., 2014, 'Teori Pendidikan Keluarga dan Tanggung Jawab Orang Tua dalam Pendidikan Anak Usia Dini', Nadwa 8(2), 245-260. https://doi.org/10.21580/ nw.2014.8.2.580

Jalaludin, H., 2005, Psikologi Agama, PT Raja Grafindo Persada, Jakarta.

James, W., 2014, The varieties of religious experience: A study in human nature being the Gifford lectures on natural religion, Harvard University Press, Cambridge.

Krori, S.D., 2011, 'Develomental psychology', Homeopathic Journal 4(3), n.p.

Marwoko, G.C., 2019, 'Psikologi Perkembangan Masa Remaja', Journal of Pedagogy 26(1), 60-75.

Mulyana, D. \& Jalalludin, R., 2005, IImu Komuniasi Suatu Pengantar, PT. Remaja Rosdakarya, Bandung. 
Rahmah, S., 2017, 'Peran Keluarga Dalam Pendidikan Akhlak', Al-Hiwar: Jurnal IImu dan Teknik Dakwah 4(6). https://doi.org/10.18592/al-hiwar.v4i6.1213

Reyes, G.M., 2006, 'Spirituality and religiosity: Their relation to academic achievement of undergraduate college students', dissertation, Northern Arizona University, Arizon.

Sani, S.A., 2013, Inovasi pembelajaran, Bumi Aksara, Jakarta.

Saputri, M.A., 2018, 'Pengaruh Komunikasi Interpersonal antara Orang Tua dan Anak dalam Meningkatkan Akhlakul Karama (Studi Terhadap Masyarakat Jl. Baru Telkom Rt 004 Kelurahan Talang Ubi Timur, Kecamatan Talang Ubi, Kabupaten PALI)', Jurnal Komunikasi Islam Dan Kehumasan (JKPI) 2(1), 62-83. https://doi. org/10.19109/jkpi.v2i1.2752
Sarwono, S., 2011, Psikologi Remaja, PT Rajagrafindo Persada, Jakarta.

Shubert, J., 2011, Human comunication; Concepts, principles, and skill, Department of Communication, Michigan State University, East Lansing, MI.

Sihabudin, S., 2014, Komunikasi Antarbudaya Mahasiswa Asean di UIN Sunan Ampe Surabaya, UIN Sunan Ampel Surabaya, Surabaya.

Sugiyono, 2019, Metode Penelitian Pendidikan: Kuantitatif, Kualitatif, Kombinasi, $R \& D$, Alfabeta, Bandung.

Yunus, M., 1990, Sedjarah pendidikan Islam di Indonesia, Jakarta, Pustaka Mahmudiah. 